\begin{tabular}{|l|l|l} 
Informing Science: & $\begin{array}{c}\text { An Official Publication } \\
\text { the International Journal of } \\
\text { of the Informing Science Institute } \\
\text { InformingScience.org }\end{array}$ \\
\hline
\end{tabular}

Volume 20, 2017

\title{
THE EFFECT OF IT INTEGRATION ON SUPPLY CHAIN AgILITY TOWARDS MARKET PERFORMANCE (A PROPOSED STUdY)
}

\begin{tabular}{|c|c|c|}
\hline Shaghayegh Maleki Far* & $\begin{array}{l}\text { RMIT University, Ho Chi Minh } \\
\text { City, Vietnam }\end{array}$ & shaghayegh.malekifar@,rmit.edu.vn \\
\hline Mohammamadreza Akbari & $\begin{array}{l}\text { RMIT University, Ho Chi Minh } \\
\text { City, Vietnam }\end{array}$ & reza.akbari@,rmit.edu.vn \\
\hline Steven Clarke & $\begin{array}{l}\text { RMIT University, Ho Chi Minh } \\
\text { City, Vietnam }\end{array}$ & steven.clarke@,rmit.edu.vn \\
\hline
\end{tabular}

\begin{abstract}
Aim/Purpose An important objective of any firm is escalation of its performance and the achievement of competitive advantages. Supply chain agility plays a prominent role to enhance the level of firm's performance. Moreover, information technology (IT) plays a foundational role in supply chain management practices. Hence, this study proposes the relationship between IT integration as the competency of IT and firm's market performance both directly and through mediating role of supply chain agility.
\end{abstract}

Background Many studies have been done to date on the impact of supply chain agility on overall firm's performance. However, the effect of an agile supply chain on firm's market performance per se needs to be studied. Furthermore, there is a gap in the literature about the effect of IT competency such as IT integration on firm's market performance both directly and through mediating role of supply chain agility.

Recommendation The first direction this study gives to researchers is to consider the different facfor Researchers tors which have significant effect on the agility of supply chain, particularly the IT related ones. The second direction is about the study on the effect of IT competencies and supply chain agility on each category of firm's performance separately instead of considering it as a one construct.

Impact on Society Although this is a conceptual study, it can highlight the importance of IT competency not only in our daily life, but also in our businesses and industries.

Future Research This study only proposes some relationships based on theory and literature. Future researchers can test these proposed relationships in different contexts and

Accepting Editor Raafat Saadé | Received: January 3, 2017| Revised: May 12, 2017 | Accepted: May 15, 2017. Cite as: Maleki Far, S., Akbari, M., \& Clarke. S. (2017). The effect of IT integration on supply chain agility towards market performance (A proposed study). Informing Science: the International Journal of an Emerging Transdiscipline, 20, 99-117. Retrieved from http://www.informingscience.org/Publications/3747

(CC BY-NC 4.0) This article is licensed to you under a Creative Commons Attribution-NonCommercial 4.0 International License. When you copy and redistribute this paper in full or in part, you need to provide proper attribution to it to ensure that others can later locate this work (and to ensure that others do not accuse you of plagiarism). You may (and we encourage you to) adapt, remix, transform, and build upon the material for any non-commercial purposes. This license does not permit you to use this material for commercial purposes. 
compare the results. Furthermore, this study proposes the relationships for large manufacturing sector in developing countries. The model could be tested for SMEs as well. In addition, the proposed theoretical model in this study might be tested in both developing as well as developed countries to compare the results which will be contributed to the body of knowledge.

Keywords IT integration, supply chain agility, market performance

\section{INTRODUCTION}

Nowadays, firms struggle with negative and positive impacts of global competition, prompt changes in customers' demands, and preferences due to the global competition, as well as faster pace of revolution in technologies. Therefore, the capability of a firm to sense and respond to these changes in the marketplace is an exigent core competence (Ganguly, Nilchiani, \& Farr, 2009). This competency is vital to firms that should recognize and communicate market changes, and organize corresponding responses to the changes via an integrated supply chain (DeGroote \& Marx, 2013). In addition, this core competency is captured in the idea of 'agility' (Sharifi \& Zhang, 1999). Agile firms quickly sense changes in the market and implement coordinated and corresponding responses, which contributes to attaining competitive advantages such as critical first-mover over their rivals (Blome, Schoenherr, $\&$ Rexhausen, 2013). The advantages of IT such as information and communication contribute to the agility of the supply chain that creates the opportunity to identify and coordinate supply chain responses to probable market changes (DeGroote \& Marx, 2013, Sambamurthy, Bharadwaj, \& Grover, 2003).

On the other side, information has become a critical resource in the global market, not only for large enterprises, but also for SMEs (Julien \& Ramangalahy, 2003). Moreover, one reappearing environmental factor which is included in many studies is environmental uncertainty (e.g., Aitken, Childerhouse, Deakins, \& Towill, 2016; Frohlich \& Westbrook, 2002; Gligor, Holcomb, \& Feizabadi, 2016; Hult, Ketchen, \& Arrfelt, 2007; Kipley, Lewis, \& Jewe, 2012; Patterson, Grimm, \& Corsi, 2003; Swafford, Ghosh, \& Murthy, 2006; K.-J. Wu, Tseng, Chiu, \& Lim, in press). Dröge \& Germain (1998) assumed that the uncertainty in the environment may be characterized by a wide variety of factors including unforeseeable changes in customers' demands and competitors' action, unreliability of suppliers in aspects of quantity and quality, rapid price fluctuation, and rapid shifts in production processes. For each type of uncertainty a different type of capability might be effective to response efficiently. Undoubtedly, an efficient response is linked to strategic capabilities of a firm which are agility and flexibility particularly in its supply chain processes and functions (Fayezi, Zutshi, \& O'Loughlin, 2016). An alternative view for the existence of uncertainty is the lack of valid and reliable information in firms to make the best decision (Patterson et al., 2003). On the other side, as Sambamurthy, Bharadwaj, and Grover (2003) claimed, advancements, innovations, and progress in information technologies have motivated various studies on the role of IT in speeding up the level of agility. Firms can realize considerable benefits from investment in information technology that develops and increases agility.

Moreover, it is notable that supply chain agility plays an important role in enhancing the level of informing clients, suppliers, and consumers by getting benefit from information technology. As Gill \& Bhattacherjee (2007) mentioned, there is a technology media environment between sender (e.g., business or supply chain) and receiver (e.g., client). However, there are many factors which make the real world more complex such as multiple supply chains may inform the same customer about their products or services and/or any changes in order to compete in their market (Gill \& Cohen, 2008). According to Gill (2008), there are three general informing issues between sender (e.g., supply chain) and receiver (e.g., customer): 1) information about the knowledge of prior client, 2) recognition and comprehension the particular bottlenecks to performance of the tasks being carried out, and 3) understanding the reason that clients have motivation for being informed. The agile supply chain has the advantage to sense the market changes and customers' preferences rapidly and inform them 
swiftly about the coming changes and/or innovations in the product or service through informing systems which rely on informing science. It facilitates the agile supply chain to have a close relationship with its customers compared with other rivals.

An important objective of firms is to achieve competitive advantage and escalation of the firm's performance. Moreover, reviewing the literature revealed that among different supply chain management practices, supply chain agility plays a prominent role to enhance the level of the firm's performance (e.g., Blome et al., 2013; Bottani, 2009, Eckstein, Goellner, Blome, \& Henke, 2015; Kabra \& Ramesh, 2016; Khan \& Pillania, 2008; Swafford, Ghosh, \& Murthy, 2008; Yusuf \& Adeleye, 2002). Although many scholars studied the impact of supply chain agility on overall firm's performance, its effect on the firm's market performance per se in the context of large manufacturers needs to be studied precisely.

Furthermore, most studies done to date have examined the impact of different organizational practices on supply chain agility in developed countries such as US and UK (e.g., Blome et al., 2013; Bottani, 2009; Braunscheidel \& Suresh, 2009; Swafford et al., 2008). However, some developing countries such as Malaysia, Vietnam, and Thailand are entering the global market very fast. For example, in aspect of Logistics Performance Index among 160 countries Malaysia, Thailand and Vietnam are ranked $32^{\text {nd }}, 4^{\text {th }}$ and $64^{\text {th }}$ respectively (World Bank, 2016). It might be a good reason that these countries are emerging as primary manufacturing hubs for many multinational companies, and international manufacturers. To be capable to survive and compete in the global market, the strong and powerful infrastructure and foundation especially in supply chain management activities and their agility is vital. Some studies investigated the impact of some IT related variables such as IT adoption (Zain, Rose, Abdullah, \& Masrom, 2005), ICT tools (Bottani, 2009), ERP systems (Shatat \& Udin, 2012b) and industry supporting technology (Sukati, Hamid, Baharun, Yusoff, \& Anuar, 2012) on the agility of supply chain in the context of developing countries' manufacturers. However, it has been revealed that there is a gap in the literature regarding the effect of IT integration on supply chain agility in large manufacturers in developing countries such as Malaysia as one of the fast developing countries not only in South-East Asia, but also in the global market.

Malaysia is one of the members of the Association of Southeast Asia Nation (ASEAN) and one of the pioneers to use of IT practices in most of its firms and organizations. Since 2004 until 2013 the AT Kearney's Global Services Location Index (formerly known as the Offshore Location Attractiveness Index) ranked Malaysia as the $3^{\text {rd }}$ most attractive business location for business process outsourcing, behind India and China (AT Kearney, 2014). Moreover, out of 160, Malaysia is ranked $26^{\text {th }}$ in the world among the countries in which ICT tools are used by its agile business sector to get benefit from their advantages The Global Information Technology Report. (2016). Since Malaysia is a

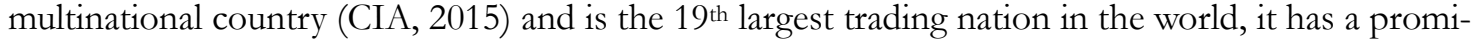
nent manufacturing sector which contributes almost $80 \%$ of the overall country's export. Malaysian manufacturers, same as manufacturers in other countries, are competing head to head to get the higher level of market performance. In doing so, attracting new customers, finding new market, and capturing market share are vital for the manufacturers. Due to the regional and local stiff competition, the manufacturers of Malaysia are tending to be more vigilant and prudent to have a smooth and flawless supply chain which would make the way to get more customers, market share and also gain customer trust.

The next section reviews the most relevant literature about market performance and its enhancement through supply chain agility, literature about supply chain agility per se, the variables which influence the agility of supply chain, and IT integration respectively. Later, a theoretical framework will be presented by considering the theory foundation of this study (i.e., resource-based view) as well as supportive literature which results in developing four propositions. Finally, some directions for future studies will be addressed. 


\section{LITERATURE REVIEW}

A firm's performance measurement system plays an imperative role in the management of the business as it provides the necessary information for decision-making and actions (Gunasekaran \& Kobu, 2007). An important objective of the firms is to achieve competitive advantages and escalation of firm's performance. Therefore, one of the items needs to be precisely measured is firm's performance. By identifying suitable measurement for the firm's performance, clear communication between employees will be facilitated, and it will help firm to improve its performance (Gunasekaran \& Kobu, 2007).

It is unfortunate that many companies fail to understand the significance of balanced approach to the firm's performance measurement (Davig, Elbert, \& Brown, 2004). Some scholars such as Parker (2000) and Gunasekaran and Kobu (2007) highlighted that it is commonly understood that financial performance measures are important for taking strategic decisions; however, at the same time, for day-to-day control of manufacturing and distribution operations, non-financial measures such as customer satisfaction and new customers attraction as dimensions of firm's market performance are also imperative in firms. Hence, this study focuses on firm's market performance as a strategic tool to reach to competitive advantages.

\section{MARKET PERFORMANCE}

In general, a firm's performance is a broad concept that covers different dimensions of the firm's activities. Although there are many studies on financial performance, non-financial performance indicators have been addressed in the literature to enhance the overall firm's performance such as operational performance and market performance (Tseng \& Liao, 2015). Market performance refers to financial indicators that reflect market goals in respect to meet the customer needs (Golicic \& Smith, 2013). These financial indicators are mainly, market share, competitive advantage, customer loyalty, brand equity, etc. Recently, Chin, Lo, and Ramayah (2013) noted that market performance refers to market share growth, profit ratio, and customer satisfaction. They concluded that when a firm has a good outcome in its market share or profit ratio, it means the market performance of the firm is acceptable and significant. On the other hand, they believed that an increase in customer satisfaction level is in the line with increasing market performance.

Moreover, Ottenbacher (2007) measured market performance through the indicators, namely, opening new markets, attracting new customers and market share. Ottenbacher (2007) believed that some factors, including market responsiveness, effective marketing communication, raising awareness and tangible quality, have an influence on a firm's market performance. Furthermore, Sin, Tse, Heung, \& Yim (2005) measured market performance through customer retention, trust, and customer satisfaction. The next section reviews the different supply chain management practices which enhance a firm's market performance.

\section{ENHANCING MARKET PERFORMANCE THROUGH SUPPLY CHAIN MANAGEMENT PRACTICES}

According to F. Wu, Yeniyurt, Kim, and Cavusgil (2006), among many factors, enhancing supply chain as a capability of a firm can affect the firm's performance in different ways. First of all, the flow of information can potentially increase the sales volume when a new product is introduced to the market and by tapping into inaccessibale markets on account of distribution or other infrastructure constraints. Second, the huge benefits achieved via an integrated system give opportunity to a firm to respond to customers' problems, requests, demands, and preferences more efficiently. For instanse, through its interface with customer relationship management (CRM), supply chain allows a business to respond to its customer inquiries, track their orders, and provide wider after-sale service. 
Information sharing in the supply chain can diminish the uncertainty level in demand (Frohlich \& Westbrook, 2002). Also, it can facilitate a firm to produce and deliver products and/or services to consumers at an efficient level of speed and cost through the improved harmonization among supply chain partners (F-r Lin, Huang, \& Lin, 2002). In addition, a seamless supply chain simplifies the organizational processes and diminishes lead times. It makes a firm capable of modifying its strategies and implementing them throughout the supply chain ahead of rivals whenever opportunities arise. This can eventually boost shareholder value due to flexible business processes (F. Wu et al., 2006).

According to the literature, in the context of supply chain management there is much research to show the different factors which have impact on a firm's performance. Most of these studies were conducted in developed countries such as US and UK (e.g., Chen, Paulraj \& Lado, 2004; DeGroote \& Marx, 2013; Golicic \& Smith, 2013; Hult, Ketchen, Adams, \& Mena 2008; S. Li, Ragu-Nathan, Ragu-Nathan, \& Subba Rao, 2006). While in the context of fast developing countries like Malaysia there are few studies in which researchers investigated the impact of some variables such as supply chain management practices on a firm's performance (e.g., Agus \& Hajinoor, 2012; Chong, Chan, Ooi, \& Sim, 2011; Wong \& Wong, 2011). Moreover, reviewing the literature shows that most of the studies considered the overall firm's performance rather than different categories of performance such as financial, market, and operational. Furthermore, the majority of these studies investigated the impact of supply chain management practices, specifically supply chain agility, on either operational or overall performance. Hence, the impact of supply chain management practices on market performance, particularly in fast developing countries, needs to be explored precisely.

All the definitions of supply chain management bring the glimpse view that the supply chain has to be aligned with the internal and external environment of the firm. And to do so, a firm must consider the complexity and dynamism of the environment as fast as possible that will raise the concern on supply chain agility. For example, Tseng and Liao (2015) claimed that shortening the lead time between a customer's order and its delivery contributes to the firm's operational visibility and then results in a streamlined flow of goods. This strategy eventually enhances the level of a firm's market performance as it increases the level of customers' satisfaction. Supply chain agility is one of the critical practices in the context of supply chain management which allows firms to sense and respond to market changes quickly.

\section{SUPPLY CHAIN AGILITY}

In today's global marketplace, a key element of success is a firm's ability to respond and cope with challenges and sustain its competitive advantage (Prahalad \& Hamel, 1990; Swafford et al., 2008). The dynamic and vibrant nature of the market explicates the necessity of agility as a necessary element for a firm's success and survival in an extended period of time. To meet the customer needs and demands, supply chain has become an important issue for companies. And the agility of supply chain is also a significant issue due to the fact that business firms need to build up their supply chain that is flexible and responsive (Braunscheidel, Suresh, \& Boisnier, 2010).

Earlier in the literature, Huang, Uppal, and Shi (2002) noted that the purposes of agile supply chains are to comprehend customer requirements by connecting with the market, adapt to future changes, and produce with customization to deliver into a wide variety of market niches simultaneously. The authors outlined that agile supply chain arranges significant safety stocks to overcome any unpredictable market requirement and invests aggressively to diminish lead times and delivery cost (Huang et al., 2002).

Supply chain agility is taken into account as one of the operational strategies of firms to be fast and flexible. In the same line, Lee (2004) postulates that the main objective of agility in supply chain is to respond to demand or supply changes quickly and to manage external disruptions efficiently. Therefore, Swafford et al. (2006) believe that implementing the concept of agility in supply chain enables a manufacturer to achieve higher overall organizational agility. Scholars argue that the firms are con- 
stantly scanning the environment to respond and adapt to changes in customers' needs and transforming supply settings. Yet, the firms should proactively look for ever-present potential of supply chain disruptions (e.g., Wagner \& Silveira, 2012). In this perspective, supply chain agility can be defined as the combination of a firm's capability and its key customers and suppliers to rapidly and effectively react to its environment changes (Braunscheidel \& Suresh, 2009). Inherently, this conceptualization refers to a firm's flexibility and its ability to carry out rapid and successful reconfiguration of key resources to stay competitive (Blome et al., 2013).

Turning away from the business environment, it has been evidently proved by some natural disasters (e.g., earthquake and tsunami in Japan) that disrupted supply chain incurred significant loss of overall environment along with incomprehensible human tragedy (BBC, 2011). Considering such turbulent situations, agility should enable firms to react more effectively to supply chain disruptions originating from this environment. While usually disruptions are limited in time, breadth, and scope, it might be cushioned by safety stock; therefore, it could be avoided by an agile supply chain, eventually contributing to optimized supply chain costs (Blome et al., 2013).

The agile supply chain is highly market responsive, as it can react to sudden demand peaks. It can also be said that agility alone is a prerequisite for the competition rather than to provide a competitive advantage in supply chains (Blome et al., 2013). To attain competitive advantage, while supply chain agility focuses on customer responsiveness in an unexpected market (van Hoek, Harrison, \& Christopher, 2001), it is necessary to ensure the firm's competitiveness such as procurement, manufacturing, delivery, and market promotion (Agarwal, Shankar, \& Tiwari, 2007; Sambamurthy et al., 2003; Swafford et al., 2006).

Moreover, supply chain agility facilitates firms to offer new products rapidly and recurrently considering the strength of the interactions between the procurement, manufacturing, and distribution (Swafford et al., 2006). According to Katayama and Bennett (1999), the level of supply chain agility shows the power of the connection between a firm and its marketplaces. In a study, Malekifar, Taghizadeh, Rahman, and Khan (2014) discussed that IT competency has a positive impact on supply chain agility. The authors considered supply chain agility as two steps of sense and response. Since agility facilitates a firm to rapid and effective response to market changes (Mason-Jones \& Towill, 1999), therefore, it is required to consider the speed-related measures (Chan, Ngai, \& Moon, 2017).

\section{REVIEW OF VARIABLES INFLUENCING SUPPLY CHAIN AGILITY}

According to the relevant literature, most of the studies done to date investigated or examined the impact of different organizational practices on supply chain agility. These practices mostly rely on variables such as process flexibility, process integration, supply chain flexibility, manufacturing flexibility, firm's internal and external flexibility, customer satisfaction, and sourcing strategies (e.g., Agarwal et al., 2007; Bottani, 2009; C-T Lin, Chiu, \& Chu, 2006; Swafford et al., 2006, 2008; Zain et al., 2005). Moreover, the context of most of them is developed countries such as US, UK, and Germany (e.g., Blome et al., 2013; Bottani, 2009; Braunscheidel \& Suresh, 2009; DeGroote \& Marx, 2013; Swafford et al., 2008). Recently, Gligor (2016) discussed that an agile supply chain facilitates firms to gather information about demand and supply changes in their internal and external environments quickly, determine what actions and reactions are required to cope with the changes, and implement their supply chain related actions as fast as possible. In fact, without getting benefit from IT facilities, these quick actions and reactions would not be possible.

Some of the studies investigated the impact of some IT related variables such as IT adoption, ICT tools, ERP systems, and industry supporting technology on the agility of supply chain in the context of developing countries such as Malaysian manufacturers. For example, Zain et al. (2005) studied the relationship between IT adoption and agility among Malaysian manufacturers. The results of their study revealed that the usage of technology plays the most important role in enhancing the agility of organizations. In another study, Shatat and Udin (2012a) studied the improvement of supply chain management performance through the successful usage of ERP systems in the context of Malaysian 
manufacturers. The findings of their study indicated that usage of ERP systems has a positive and significant impact on supply chain performance in many aspects such as accelerating of information flow among different departments and improvement of collaboration with suppliers and customers. In addition, Sukati et al. (2012) examined the relationship between industry supporting technology and supply chain agility of manufacturers in Malaysia. The results of their study showed that supporting technology has a positive and significant effect on agility of supply chain among Malaysian manufacturers.

Extensive review of the relevant literature highlights that there is a gap in the literature regarding the impact of IT integration on supply chain agility in the context of developing countries' manufacturing sector. In fact, IT integration as one of the valuable resources of a firm can play a key role to accelerate the organizational processes and operations. Some research focused on improving supply chain agility through IT competence, while they considered this competency as a dimension of supply chain competence and the effect of agile supply chain on firm's performance in their study is overlooked (e.g., Nagi, Chau, \& Chan, 2011). In other words, research on the impact of IT integration per se on agility of supply chain in the context of developing countries' large manufacturers needs to be studied.

Furthermore, a few studies investigated the impact of IT competence on supply chain agility and effect of its outcome on different categories of firm's performance. For instance, Swafford et al. (2008) studied about improving supply chain agility through IT integration and its effect on enhancement of overall competitive business performance. Moreover, DeGroote asnd Marx (2013) studied the impact of IT on abilities of sense and response in an agile supply chain. Also, they investigated the impact of agile sense and response on firm's performance separately. In their study, a firm's performance was considered as an overall performance and the definition of IT in their study was about usage of IT tools. Therefore, there is a gap in the literature on the impact of IT integration on supply chain agility and different categories of firm's performance such as firm's market performance. According to the literature and the gaps which were found in this section, IT integration and its effect on supply chain agility is the interest of the current study.

\section{IT INTEGRATION}

IT integration defines the conceptualization of information systems which are connected and shared among different entities (Knapp, Marshall, Rainer, \& Ford, 2006; C-T Lin et al., 2006). According to Swafford et al. (2008), IT integration is the degree to which IT is used to integrate information within a firm's functions and with firms within their supply chain. Technically, IT integration synchronizes supply chain functions and creates partnership by sharing information which is related to forecasting demand, scheduling production, as well as inventory and production quality (G. Li, Yang, Sun, \& Sohal, 2009). Moreover, IT integration enables firms to share knowledge within the context of supply chain. Further, IT integration incorporates the exchange of knowledge together with partners located vertically in the supply chain (Nagi et al., 2011). In addition, the benefit of IT integration is to provide efficient, timely, and transparent business information towards the concerned associates in order to reduce the required time for knowledge sharing (Pearcy \& Giunipero, 2008).

By possessing an integrated information system, a supplier can enter the customer inventory information and prepare entailed stock delivery in a timely way (Bagchi \& Skjoett-Larsen, 2003; Nagi et al., 2011). Furthermore, when a manufacturer requires fulfilling an unexpected increased demand, it can use a well-integrated IT system. Such a process will enable them to have a clear picture of the supply chain and inventory status, and the capability of the service providers (Nagi et al., 2011).

\section{THEORETICAL FRAMEWORK AND PROPOSITIONS}

The resource-based view (RBV) examines how certain resources and capabilities develop a foundation for competitive advantages and superior firm's performances (Barney, 1991). Wernerfelt (1984) supposed that resources could be either 'tangible' or 'intangible' such as the assets, organizational 
processes, information, and knowledge. These resources which are under control of the firm in order to consider and develop strategies contribute to effective and efficient operations resulting in achieving higher level of firm's performance. Later, Barney (1991) expanded the RBV theory by scrutinizing the relationship between a firm's internal characteristics and its performance. The firm's internal characteristics are the resources and capabilities to achieve their desired activities (i.e., competitive advantage).

Firms create competitive advantage by assembling resources that work together to create organizational capabilities. Capabilities refer to firm's ability to assemble, integrate, and deploy valued resources through combination or with co-presence of different resources (Amit \& Schoemaker, 1993; Russo \& Fouts, 1997). It is crucial to understand how resources are developed, configured, and exploited which can make a significant distinction leading to competitive differentiation which also lead to the dynamic capabilities concept (Allred, Fawcett, Wallin, \& Magnan, 2011; Teece, 2007). Scholars specifically pointed out that RBV assumes a firm's resources as valuable, rare, unique, and nonsubstitutable assets which also affect the firm's competitive advantage and superior firm's performance (Barney, 1991; Day, 1994; Wernerfelt, 1984). Unique and inimitable resources can construct the basis of competitive advantage and also sustainability of the firm (Lei, Hitt, \& Bettis, 1996). Under the lens of RBV, this competitive advantage along with sustainability results in the desired outcomes of the firm's managerial efforts (Barney, 1991).

According to Clemons and Row (1991), IT per se might not generate a sustainable advantage, as it can be imitated. In addition, from the perspective of RBV, competencies are inimitable because of particular development of resources which might have less value outside the context of a specific firm. This inimitability and uniqueness can form the basis of competitive advantage. Thus, firms that achieve higher levels of IT competency are supposed to be in a superior position to create their capability (Tippins \& Sohi, 2003). Hence, this study proposed IT integration as the resource of the firms. According to the classification of resources by Barney (1991), IT integration is classified as organizational capital resources.

Furthermore, in this study supply chain agility is defined as the capability of an organization to respond to market changes rapidly. In other words, in relation to RBV, this study claims that supply chain agility is a capability that facilitates an organization to sustain its competitive advantage. According to Blome et al. (2013), to have the best reaction to the dynamic environment, a dynamic capability such as fast responsiveness capability is needed. Indeed, capability is the connection that brings resources together and enables them to be organized in an advantageous mode to offer the higher level of responsiveness (Day, 1994). Similarly, in this study supply chain agility is considered as a dynamic capability.

According to Ordanini and Rubera (2010) and Kalkan, Erdil and Çetinkaya (2011), IT competency impacts performance after it satisfies the RBV's proposed conditions in terms of value, rareness, and inimitability. Hence, this study proposed that RBV supports the direct relationship between IT integration and a firm's market performance. Furthermore, this study determined IT integration as inimitable resource and supply chain agility as a capability of firms and hence, RBV supports the relationship between IT integration and supply chain agility.

In the last decade, Swafford et al. (2008) claimed that the relationship between supply chain agility (i.e., capability) and firm's performance (i.e., competitive advantage) could be supported by RBV. Moreover, Barney (2012) noted that supply chain management is a firm's capability that can create high level of expectations on the resources' future value. Hence, in this study it is proposed that RBV supports the relationship between supply chain agility and firm's market performance.

This study claims that the direct effect of IT integration on firm's market performance, the relationship between IT integration and supply chain agility and also the relationship between supply chain agility and firm's market performance are supported by RBV. Therefore, consequently, this study 
proposes the mediating effect of supply chain agility on the relationship between IT integration and firm's market performance under the lens of RBV.

The proposed conceptual framework for this study has been depicted in this section based on extensive review of the literature and under the lens of RBV theory as shown in Figure 1.

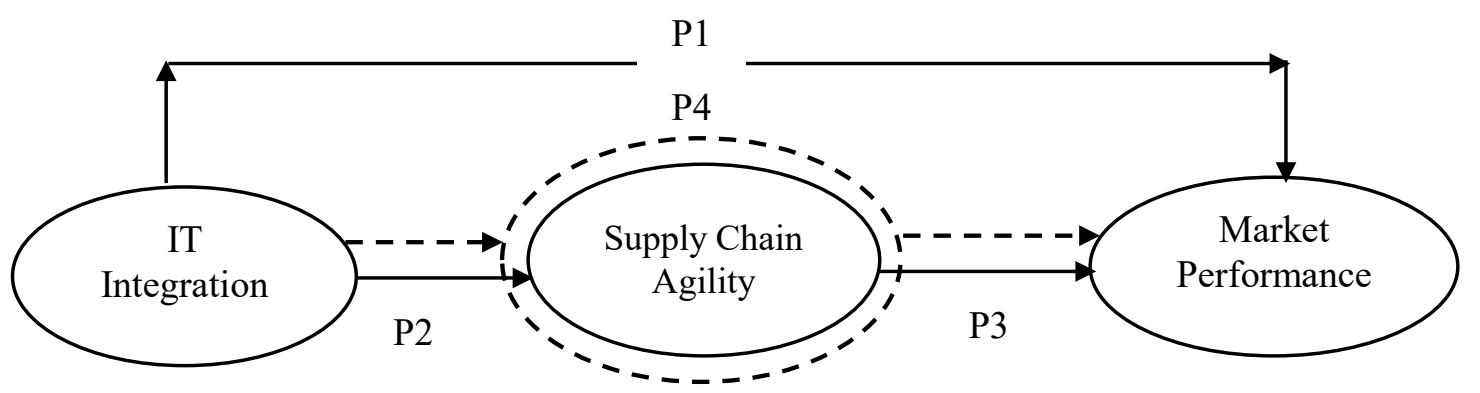

Figure 1. Theoretical model

In Figure 1, solid lines show the direct relationships between constructs. In addition, dotted lines show the mediating role of supply chain agility on the linkage between IT integration and market performance.

\section{IT INTEGRATION AND MARKET PERFORMANCE}

Adopting a resource-based perspective of IT, Bharadwaj (2000) has argued that since investments in IT can be easily duplicated by competitors, investment by itself does not provide any sustained advantages. In other words, there is evidence that many firms are engaged in high level of IT investment without gaining any benefits from their investment. Hence, despite high level of investments in technology, IT resources and IT skills incline to be distributed heterogeneously across firms, leading to different patterns of IT usage and effectiveness.

The resource-based perspective of IT recommends that organizations can differentiate themselves on the foundation of their IT resources. In a firm, IT infrastructure, human IT skills, and ability to leverage IT for intangible benefits serve together as the specific resources of a firm to create a firmwide IT capability. As these IT resources are complex to procure and challenging to duplicate, firms who attain competitive advantage through IT also learned to combine their IT resources in an effective manner to create an overall IT competence (Bharadwaj, 2000). Similarly, it has been observed that successful firms employ technology-based skills and human IT skills for developing IT-enabled intangible resources such as customer orientation as well as superior organizational knowledge (Melville, Kraemer, \& Gurbaxani, 2004).

In a study, Tippins and Sohi (2003) found that IT has a significant impact on a firm's performance by mediating role of organizational learning. Earlier, some researchers noted that IT alone does not have significant effect on firm's performance (Devaraj, Ow, \& Kohli, 2013; Mahmood \& Soon, 1991; Shaker \& Covin, 1993). In addition, Swafford et al. (2008) examined the effect of IT integration on overall business performance through supply chain flexibility and supply chain agility. The results showed that there is a domino effect between IT integration, supply chain flexibility, supply chain agility, and business performance. In fact, the authors claimed that IT integration contributes to higher overall business performance by tapping the supply chain flexibility which in turn accelerates the agility of supply chain.

Some scholars studied the effect of different IT related variables on different classifications of firm's performance. For example, Melville et al. (2004) highlighted that successful firms employ technologybased skills and human IT skills for developing ITT-enabled intangible resources such as customer orientation, synergy, and superior organizational knowledge. Firms that are successful in creating su- 
perior IT competence, in turn enjoy superior financial performance by revenue growth and/or reduction in costs. Earlier, some scholars pointed out that IT alone does not have significant effect on a firm's performance (Mahmood \& Soon, 1991, Shaker \& Covin, 1993); however, in another study, Ordanini and Rubera (2010) highlighted two approaches regarding the impact of IT on firms' performance. The first approach is the indirect effect of IT on business performance through several key business features such as flexibility. While in their second approach IT directly enables business performance.

In a case study by Olugbode, Elbeltagi, Simmons, and Biss (2008) on the "Beale and Cole" company in England, it has been revealed that although the level of the company's business growth was significant, its existing IT infrastructure was incapable of efficiently sustaining their level of growth. Therefore, the company made beneficial and major alterations through the implementation of computerized accounting and operational systems instead of the manual ones. Currently, the company gets benefit from a fully supported and integrated IT system which maintains its competitive advantage successfully. In another case study on logistics companies in Hong Kong and the Pearl River Delta region, it has been revealed that through IT implementation in logistics departments, the companies enhance their performance regularly, which creates a significant level of competitiveness for them (Choy et al., 2014).

Extensive review of the literature revealed that although there is much research on the linkage between IT-related variables and firms' performance, research on investigating the effect of IT integration on firms' market performance is overlooked. Hence, to study on the gap regarding the direct effect of IT integration on firms' market performance and under the lens of RBV theory, the following proposition is presented in this study:

Proposition 1: The greater the level of IT integration, the higher the level of market performance

\section{IT INTEGRATION AND SUPPLY CHAIN AGILITY}

Scholars argue that in sense and response capabilities of a firm IT plays an essential role (C-T Lin et al., 2006; Sambamurthy et al., 2003). As said by Nagi et al. (2011), coordinating all the crucial IT actions can provide a way forward towards achieving supply chain agility which is very critical. Scholars suggested that an agile supply chain deploys new technologies and methods, and utilizes information systems/technologies and data interchange facilities (Huang et al., 2002). On the other hand, recently, Giannakis and Louis (2016) noted that the computational capability of some information systems face some barriers such as limitation in analysis of large groups of data, raw data, as well as the data which are complex to integrate and which might be more productive through data mining analysis.

Firms should be able to contribute in planning and executing for a synchronized response. Therefore, responding to market changes is determined by the role of IT in the firm's capability improvement to develop and implement a corresponding plan that is measured by timeliness, cost, and quality of the plan (DeGroote, 2011; DeGroote \& Marx, 2013). Responding to market changes also necessitates a firm collaborate within the players of its supply chain in order to ensure an effective and efficient response.

In such regard, IT also can improve a firm's ability to respond to volatile markets (Bhatt \& Grover, 2005) by coordinating a plan in the supply chain that refers to the market changes in a timely, precise, and cost-effective manner (Porter, 1991; Prahalad \& Hamel, 1990; Teece, Pisano, \& Shuen, 1997; Yusuf, Gunasekaran, Adeleye, \& Sivayoganathan, 2004). In fact, IT can reduce the time, total cost, and increase the effectiveness of developing and implementing a well-suited plan across the supply chain (DeGroote, 2011; DeGroote \& Marx, 2013; Goldsby \& Stank, 2000).

Various supply chain management software solutions are being developed to fulfill the requirements of all phases of the supply chain. These tools aid in processing, recording, editing, and updating all the data which are related to transactions in more accurate, methodical, and quick mode. Quicker and faster flow of information makes the supply chain more agile (Pandey \& Garg, 2009). Then, supply 
chain agility can provide a positive influence to the company by the environment of competition and IT, and consequently it influences supply chain performance to achieve competitive advantage $(\mathrm{H}$. L. Lee, 2004).

Scholars believe that information sharing is very beneficial for accelerating collaboration and cooperation in the supply chain (Du, Lai, Cheung, \& Cui, 2012; Khan, Hussain, \& Saber, 2016). In other words, the authors claimed that information sharing generates more productive partnerships among supply chain partners and creates integration between supply chain players such as suppliers and manufacturers which contributes to higher level of firm's performance. Recently, Kim and Chai (2017) studied the impact of information sharing on improving the agility of supply chain among manufacturers of South Korea. The authors concluded that information sharing has a significant and positive impact on supply chain agility. In fact, information sharing is one of the benefits of IT integration which facilitates firms to integrate information in different practices such as logistics and distribution, procurement, and manufacturing (Swafford et al., 2008).

Although many scholars studied the effect of IT-related variables on agility of supply chain, research on investigating the effect of IT integration per se on supply chain agility in the context of developing countries is overlooked. Hence, to study on the gap regarding the direct effect of IT integration on supply chain agility and under the lens of RBV theory, the following proposition is presented in this study:

Proposition 2: The greater the level of IT integration, the faster the level of supply chain agility

\section{SUPPLY CHAIN AGILITY AND MARKET PERFORMANCE}

Modern firms are now battling in the context of 'supply chain versus supply chain', moving away from a 'firm versus firm' context. Within this perspective, best value supply chains are evolving as a means to create competitive advantages and deliver superior performance. Best value supply chains surpass along an array of unique priorities such as cost, quality, speed, and flexibility (Ketchen \& Hult, 2007). Supply chain agility as a competitive capability will also ultimately lead to the achievement or maintenance of competitive position of a firm ( Blome et al., 2013; Eisenhardt \& Martin, 2000).

Explicitly, a firm's supply chain agility is most likely unique, based on the firm's specific supply-side and demand-side competencies (Blome et al., 2013). Agility has consequently evolved over an extended period of time, and regularly creates linkage to both upward and downward supply chain entities. This would turn agility into a strategic capability under the lens of RBV theory. Blome et al. (2013) in their study pointed out that supply chain agility fosters and restructures the resources to fall back to in order for a quick and effective response to dynamic changes, both on the supply-side and demand-side in ever-changing marketplace. Therefore, it has a practical importance to supply chain management.

Similarly, Yusuf and Adeleye (2002) empirically found that agile manufacturers have higher performance in comparison with other manufacturers. The results indicated that simultaneous pursuit of all competitive objectives has the potential for higher levels of performance achievement. In order to retain competitive position, firms have to react to the changing environment which can be materialized by supply chain agility (Blome et al., 2013). Therefore, it can be assumed that an agile supply chain could act as a rare, valuable, and inimitable operational capability, which improves the firm's performance (Mithas, Ramasubbu, \& Sambamurthy, 2011; Swafford et al., 2008).

For example, Tse, Zhang, Akhtar, and MacBryde (2016) found that supply chain agility has a positive and significant impact on firm's financial performance among Chinese electronics firms. Similarly, K.-J. Wu et al. (in press) claimed that supply chain agility plays a critical role to attain competitive advantage of Taiwanese electronics manufacturers. However, still there is a gap in the literature about the effect of supply chain agility on firm's market performance particularly among large manufactur- 
IT Integration and Supply Chain Agility on Market Performance (A Proposed Study)

ers of developing countries. Therefore, by considering the relevant literature and resource-based perspective, the following proposition is presented in this study:

Proposition 3: The faster the level of supply chain agility, the higher the level of market performance

\section{MEDIATING EFFECT OF SUPPLY CHAIN AGILITY}

Point of sales' scanners allows companies to capture the customer's voice. Electronic data interchange (EDI) allows all stages of the supply chain to hear that voice and react by using flexible manufacturing, automated warehousing, and rapid logistics. New concepts in the real world, such as quick response, efficient consumer response, accurate response, mass customization, lean manufacturing, and agile manufacturing offer models for applying these new technologies to improve performance (Fisher, 1997).

Supply chain agility was posited as a mediator in the study conducted by Swafford et al. (2008), linking the effect of IT integration and supply chain flexibility to competitive business performance. The results validated that a firm with IT integration and supply chain flexibility is more facilitated to achieve agile supply chain than concentrating only on IT integration. By investing in IT integration, a firm can increase the rate of agility which permits to exploit on inter-organizational collaborations (G. Li et al., 2009, Nagi et al., 2011).

In addition, F. Wu et al. (2006) found that supply chain capabilities such as agility play a vital role in transforming the IT-related resource to greater level of value for a firm. The firm can be able to develop channel-specific assets by exchanging information effectively in order to coordinate with supply chain associates. Through IT, supply chain capabilities allow the firm to learn and response to market changes in better and quicker ways. In addition, a firm which possesses these capabilities can protect itself from immediate competitive imitation. Recently, Mavengere, Mäkipää, and Ruohonen (2013) conceptually argued that information systems play a vital role in enhancing the required strategic agility dimensions in different parts of the supply chain.

Many of the scholars studied the mediating role of supply chain agility on the linkage of different variables. For instance, Eckstein et al. (2015) studied the mediating role of supply chain agility on the relationship between supply chain adaptability and cost performance as well as operational performance among German firms. Furthermore, Tse et al. (2016) focused on Chinese electronics industry and studied the mediating role of supply chain agility on the effect of supply chain integration and external learning on firm's performance respectively. In addition, Chan et al. (2017) claimed that in the fashion industry of Hong Kong, both strategic and manufacturing flexibility affect supply chain agility positively. The results of their study show that, although strategic flexibility has a direct and positive impact on firms' performance, manufacturing flexibility does not have the same effect. Furthermore, the authors noted that supply chain agility plays a vital role in mediating the effects of both strategic flexibility and manufacturing flexibility on firms' overall performance. However, the mediating role of supply chain agility on the effect of IT integration on firms' market performance in the context of large manufacturers in developing countries needs to be studied. Therefore, according to the literature and under the umbrella of RBV, in this study the following proposition is presented:

Proposition 4: Supply chain agility has mediating effect on the relationship between the IT integration and market performance

\section{CONCLUSIONS}

It is justifiable to state that the efficient, effective, smooth and rapid supply chain assists the manufacturer to outline the game plan in the competitive market through sensing the customer's demand quickly and respond to them as fast as possible. Such instrumental and market oriented game plans 
which facilitate the firm to meet the market demand, may foster the market performance of the respective manufacturer particularly in developing countries. Hence, the implementation of the agile supply chain might increase the attraction of new customers, opening up of new markets, capturing market share, customer retention, and customer satisfaction in manufacturing sector of developing countries such as the Malaysian large manufacturers.

Moreover, it is claimed that IT competency has a significant impact on enhancing the agility of the supply chain. Hence, it is worthwhile to study the factors such as supply chain agility and IT integration that may have effect on firms' market performance among large manufacturers of developing countries like Malaysia. The importance of this study comes from the RBV perspective which is focusing on the linkage between IT integration (resource) and supply chain agility (capability) which contributes to increasing the level of firms' market performance (competitive advantage), particularly among developing countries in which implementing IT integration is growing day to day.

\section{FUTURE RESEARCH}

The current study gives some directions for future research in the context of supply chain management. First, the study will focus only on large manufacturers in developing countries such as Malaysia as one of the fast developing countries. Therefore, future researchers can test the same model of this study not only in developing countries, but also in other region or countries to compare the results. Second, this study focused on large manufacturers. The future studies can focus on SMEs as well to examine the effectiveness of defined variables in this study on their firm's performance. Third, the present study considered IT integration as one of the IT competencies. Once the proposed framework of this study is be tested, the results can serve as a guideline to the large manufacturers of developing countries such as Malaysia and help them to identify the importance of IT integration as a competence of the firms and its influence on their market performance both directly and through supply chain agility. Furthermore, future studies can find other competencies of IT such as IT flexibility to examine their effects on supply chain agility and different categories of firms' performance such as operational and financial performance.

\section{REFERENCES}

Agarwal, A., Shankar, R., \& Tiwari, M. K. (2007). Modeling agility of supply chain. Industrial Marketing Management, 36, 443-457.

Agus, A., \& Hajinoor, M. S. (2012). Lean production supply chain management as driver towards enhancing product quality and business performance. International Journal of Quality \& Reliability Management, 29, 92 121.

Aitken, J., Childerhouse, P., Deakins, E., \& Towill, D. (2016). A comparative study of manufacturing and service sector supply chain integration via the uncertainty circle model. The International Journal of Logistics Management, 27, 188-205.

Allred, C. R., Fawcett, S. E., Wallin, C., \& Magnan, G. M. (2011). A dynamic collaboration capability as a source of competitive advantage. Decision Sciences, 42, 129-161.

Amit, R., \& Schoemaker, P. J. H. (1993). Strategic assets and organizational rent. Strategic Management Journal, 14, $33-46$.

AT Kearney. (2014). The 2014 AT Kearney's Global Services Location Index. Kuala Lumpur. Available at https://www.atkearney.com/research-studies/global-services-location-index

Bagchi, P. K., \& Skjoett-Larsen, T. (2003). Integration of information technology and organizations in a supply chain. International Journal of Logistics Management, The, 14, 89-108.

Barney, J. B. (1991). Firm resources and sustained competitive advantage. Journal of Management, 17, 99-120. 
IT Integration and Supply Chain Agility on Market Performance (A Proposed Study)

Barney, J. B. (2012). Purchasing, supply chain management and sustained competitive advantage: The relevance of resource-based theory. Journal of Supply Chain Management, 48, 3-6.

BBC. 2011. Japan disaster: Supply shortages 'in three months'. BBC Business News. Retrieved 22 March 2013 from http://www.bbc.co.uk/news/business-12782566

Bharadwaj, A. S. (2000). A resource-based perspective on information technology capability and firm performance: An empirical investigation. MIS Quarterly, 24, 169-196.

Bhatt, G. D., \& Grover, V. (2005). Types of information technology capabilities and their role in competitive advantage: An empirical study. Journal of Management Information Systems, 22, 253-277.

Blome, C., Schoenherr, T., \& Rexhausen, D. (2013). Antecedents and enablers of supply chain agility and its effect on performance: A dynamic capabilities perspective. International Journal of Production Research, 51, 1295-1318.

Bottani, E. (2009). On the assessment of enterprise agility: Issues from two case studies. International Journal of Logistics Research and Applications, 12, 213-230.

Braunscheidel, M. J., \& Suresh, N. C. (2009). The organizational antecedents of a firm's supply chain agility for risk mitigation and response. Journal of Operations Management, 27, 119-140.

Braunscheidel, M. J., Suresh, N. C., \& Boisnier, A. D. (2010). Investigating the impact of organizational culture on supply chain integration. Human Resource Management, 49, 883-911.

Chan, A. T. L., Ngai, E. W. T., \& Moon, K. K. L. (2017). The effects of strategic and manufacturing flexibilities and supply chain agility on firm performance in the fashion industry. European Journal of Operational Research.

Chen, I. J., Paulraj, A., \& Lado, A. A. (2004). Strategic purchasing, supply management, and firm performance. Journal of Operations Management, 22, 505-523.

Chin, C.-H., Lo, M.-C., \& Ramayah, T. (2013). Market orientation and organizational performance: The moderating role of service quality. SAGE Open, 3, 1-14.

Chong, A. Y. L., Chan, F. T. S., Ooi, K. B., \& Sim, J. J. (2011). Can Malaysian firms improve organizational/innovation performance via SCM? Industrial Management \& Data Systems, 111, 410-431.

Choy, K. L., Gunasekaran, A., Lam, H. Y., Chow, K. H., Tsim, Y. C., Ng, T. W., Tse, Y. K., \& Lu, X. A. (2014). Impact of information technology on the performance of logistics industry: The case of Hong Kong and Pearl Delta region. Journal of the Operational Research Society 65, 904-916.

CIA. (2015). The world factbook. USA: Central Intelligence Agency.

Clemons, E. K., \& Row, M. C. (1991). Sustaining IT advantage: The role of structural differences. MIS Quarterby, 15, 275-292.

Davig, W., Elbert, N., \& Brown, S. (2004). Implementing a strategic planning model for small manufacturing firms: An adaptation of the balanced scorecard. S.A.M.Advanced Management Journal, 69, 18-24.

Day, G. S. (1994). The capabilities of market-driven organizations. Journal of Marketing, 58, 37-52.

DeGroote, S. E. (2011). An empirical investigation of the impact of information technology on supply chain agility and firm performance among U.S. manufacturers. Doctor of Business Administration, Lawrence Technological University.

DeGroote, S. E., \& Marx, T. G. (2013). The impact of IT on supply chain agility and firm performance: An empirical investigation. International Journal of Information Management, 33, 909-916.

Devaraj, S., Ow, T. T., \& Kohli, R. (2013). Examining the impact of information technology and patient flow on healthcare performance: A theory of swift and even flow (TSEF) perspective. Journal of Operations Management, 31, 181-192.

Dröge, C., \& Germain, R. (1998). The design of logistics organizations. Transportation Research Part E: Logistics and Transportation Review, 34, 25-37. 
Du, T. C., Lai, V. S., Cheung, W., \& Cui, X. (2012). Willingness to share information in a supply chain: A partnership-data-process perspective. Information \& Management, 49, 89-98.

Eckstein, D., Goellner, M., Blome, C., \& Henke, M. (2015). The performance impact of supply chain agility and supply chain adaptability: The moderating effect of product complexity. International Journal of Production Research, 53, 3028-3046.

Eisenhardt, K. M., \& Martin, J. A. (2000). Dynamic capabilities: What are they? Strategic Management Journal, 21, 1105-1121.

Fayezi, S., Zutshi, A., \& O'Loughlin, A. (2016). Understanding and development of supply chain agility and flexibility: A structured literature review. International Journal of Management Reviens, 0, 1-30.

Fisher, M. L. (1997). What is the right supply chain for your product? Harvard Business Review, 75, 105-117.

Frohlich, M. T., \& Westbrook, R. (2002). Demand chain management in manufacturing and services: Webbased integration, drivers and performance. Journal of Operations Management, 20, 729-745.

Ganguly, A., Nilchiani, R., \& Farr, J. V. (2009). Evaluating agility in corporate enterprises. International Journal of Production Economics, 118, 410-423.

Giannakis, M., \& Louis, M. (2016). A multi-agent based system with big data processing for enhanced supply chain agility. Journal of Enterprise Information Management, 29, 706-727.

Gill, G. (2008). Structural complexity and effective informing. Informing Science: International Journal of an Emerging Transdiscipline, 11, 253-279. Retrieved from https://www.informingscience.org/Publications/448

Gill, G., \& Bhattacherjee, A. (2007). The informing sciences at a crossroads: The role of the client. Informing Science International Journal of an Emerging Transdiscipline, 10, 17-39. Retrieved from https://www.informingscience.org/Publications/454

Gill, T. G., \& Cohen, E. (2008). Research themes in complex informing. Informing Science: International Journal of an Emerging Transdiscipline, 11, 147-164. Retrieved from https://www.informingscience.org/Publications/444

Gligor, D. M. (2016). The role of supply chain agility in achieving supply chain fit. Decision Sciences, 47, 524-553.

Gligor, D. M., Holcomb, M. C., \& Feizabadi, J. (2016). An exploration of the strategic antecedents of firm supply chain agility: The role of a firm's orientations. International Journal of Production Economics, 179, 24-34.

Goldsby, T. J., \& Stank, T. P. (2000). World class logistics performance and environmentally responsible logistics practices. Journal of Business Logistics, 21, 187-208.

Golicic, S. L., \& Smith, C. D. (2013). A meta-analysis of environmentally sustainable supply chain management practices and firm performance. Journal of Supply Chain Management, 49, 78-95.

Gunasekaran, A., \& Kobu, B. (2007). Performance measures and metrics in logistics and supply chain management: a review of recent literature (1995-2004) for research and applications. International Journal of Production Research, 45, 2819-2840.

Huang, S. H., Uppal, M. \& Shi, J. (2002). A product driven approach to manufacturing supply chain selection. Supply Chain Management: An International Journal, 7, 189-199.

Hult, G. T. M., Ketchen, D. J. \& Arrfelt, M. 2007. Strategic supply chain management: improving performance through a culture of competitiveness and knowledge development. Strategic Management Journal, 28, 10351052.

Hult, G. T. M., Ketchen, D. J., Jr., Adams, G. L., \& Mena, J. A. (2008). Supply chain orientation and balanced scorecard performance. Journal of Managerial Issues, 20, 526-544.

Julien, P.-A., \& Ramangalahy, C. (2003). Competitive strategy and performance of exporting SMEs: An empirical investigation of the impact of their export information search and competencies. Entrepreneurship Theory and Practice, 27, 227-245. 
IT Integration and Supply Chain Agility on Market Performance (A Proposed Study)

Kabra, G., \& Ramesh, A. (2016). Information technology, mutual trust, flexibility, agility, adaptability: Understanding their linkages and impact on humanitarian supply chain management performance. Risk, Hazards \& Crisis in Public Policy, 7, 79-103.

Kalkan, A., Erdil, O., \& Çetinkaya, Ö. (2011). The relationships between firm size, prospector strategy, architecture of information technology and firm performance. Procedia - Social and Behavioral Sciences. Paris: Elsevier Ltd. Selection.

Katayama, H., \& Bennett, D. (1999). Agility, adaptability and leanness: A comparison of concepts and a study of practice. International Journal of Production Economics, 60-61, 43-51.

Ketchen, D. J., \& Hult, G. T. M. (2007). Bridging organization theory and supply chain management: The case of best value supply chains. Journal of Operations Management, 25, 573-580.

Khan, A., \& Pillania, R. (2008). Strategic sourcing for supply chain agility and firms' performance. Management Decision, 46, 1508-1530.

Khan, M., Hussain, M., \& Saber, H. M. (2016). Information sharing in a sustainable supply chain. International Journal of Production Economics, 181, 208-214.

Kim, M., \& Chai, S. (2017). The impact of supplier innovativeness, information sharing and strategic sourcing on improving supply chain agility: Global supply chain perspective. International Journal of Production Economics, $187,42-52$.

Kipley, D., Lewis, A., \& Jewe, R. (2012). Entropy-disrupting Ansoff's five levels of environmental turbulence. Business Strategy Series, 13, 251-262.

Knapp, K. J., Marshall, T. E., Rainer, R. K., \& Ford, F. N. (2006). Information security: Management's effect on culture and policy. Information Management \& Computer Security, 14, 24-36.

Lee, H. L. (2004). The triple-A supply chain. Harvard Business Review, 82, 102-113.

Lei, D., Hitt, M. A., \& Bettis, R. (1996). Dynamic core competences through meta-learning and strategic context. Journal of Management, 22, 549-569.

Li, G., Yang, H., Sun, L., \& Sohal, A. S. (2009). The impact of IT implementation on supply chain integration and performance. International Journal of Production Economics, 120, 125-138.

Li, S., Ragu-Nathan, B., Ragu-Nathan, T., \& Subba Rao, S. (2006). The impact of supply chain management practices on competitive advantage and organizational performance. Omega, 34, 107-124.

Lin, C.-T., Chiu, H., \& Chu, P.-Y. (2006). Agility index in the supply chain. International Journal of Production Economics, 100, 285-299.

Lin, F.-r., Huang, S.-h. \& Lin, S.-c. (2002). Effects of information sharing on supply chain performance in electronic commerce. Engineering Management, IEEE Transactions on, 49, 258-268.

Mahmood, M. A., \& Soon, S. K. (1991). A comprehensive model for measuring the potential impact of information technology on organizational strategic variables. Decision Sciences, 22, 869-897.

Malekifar, S., Taghizadeh, S. K., Rahman, S. A., \& Khan, S. U. R. (2014). Organizational culture, IT competence, and supply chain agility in small and medium-size enterprises. Global Business and Organizational Excellence, 33, 69-75.

Mason-Jones, R., \& Towill, D. R. (1999). Total cycle time compression and the agile supply chain. International Journal of Production Economics, 62, 61-73.

Mavengere, N. B., Mäkipää, M., \& Ruohonen, M. (2013). Information technology role in supply chain's strategic agility. International Journal of Agile Systems and Management, 6, 7-24.

Melville, N., Kraemer, K., \& Gurbaxani, V. (2004). Review: Information technology and organizational performance: An integrative model of IT business value. MIS Quarterly, 28, 283-322.

Mithas, S., Ramasubbu, N., \& Sambamurthy, V. (2011). How information management capability influences firm performance. Mis Quarterly, 35, 237-256. 
Nagi, E. W. T., Chau, D. C. K., \& Chan, T. L. A. (2011). Information technology, operational, and management competencies for supply chain agility: Findings from case studies. The Journal of Strategic Information Systems, 20, 232-249.

Olugbode, M., Elbeltagi, I., Simmons, M., \& Biss, T. (2008). The effect of information systems on firm performance and profitability using a case-study approach. The Electronic Journal Information Systems Evaluation, $11,11-16$

Ordanini, A., \& Rubera, G. (2010). How does the application of an IT service innovation affect firm performance? A theoretical framework and empirical analysis on e-commerce. Information \& Management, 47, 60 67.

Ottenbacher, M. C. (2007). Innovation management in the hospitality industry: Different strategies for achieving success. Journal of Hospitality \& Tourism Research, 31, 431-454.

Pandey, V. C., \& Garg, S. (2009). Analysis of interaction among the enablers of agility in supply chain. Journal of Advances in Management Research, 6, 99-114.

Parker, C. (2000). Performance measurement. International Journal of Productivity and Performance Management, 49, 63-66.

Patterson, K. A., Grimm, C. M., \& Corsi, T. M. (2003). Adopting new technologies for supply chain management. Transportation Research Part E: Logistics and Transportation Review, 39, 95-121.

Pearcy, D. H., \& Giunipero, L. C. (2008). Using e-procurement applications to achieve integration: What role does firm size play? Supply Chain Management: An International Journal, 13, 26-34.

Porter, M. E. (1991). Towards a dynamic theory of strategy. Strategic Management Journal, 12, 95-117.

Prahalad, C. K., \& Hamel, G. (1990). The core competence of the corporation. Strategische Unternehmungsplanung - Strategische Unternehmungsführung, 275-292.

Russo, M. V., \& Fouts, P. A. (1997). A resource-based perspective on corporate environmental performance and profitability. Academy of Management Journal, 40, 534-559.

Sambamurthy, V., Bharadwaj, A., \& Grover, V. (2003). Shaping agility through digital options: Reconceptualizing the role of information technology in contemporary firms. MIS Quarterly, 237-263.

Shaker, Z. A., \& Covin, J. G. (1993). Business strategy, technology policy and firm performance. Strategic Management Journal, 14, 451-478.

Sharifi, H., \& Zhang, Z. (1999). A methodology for achieving agility in manufacturing organisations: An introduction. International Journal of Production Economics, 62, 7-22.

Shatat, A. S., \& Udin, Z. M. (2012a). Enterprise resource planning system; Global and Malaysian perspective. International Conference on Advances in Computer and Information Technology - ACIT 2012 Kuala Lumpur, Malaysia. theIRED, 1-16.

Shatat, A. S. \& Udin, Z. M. (2012b). The relationship between ERP system and supply chain management performance in Malaysian manufacturing companies. Journal of Enterprise Information Management, 25, 576-604.

Sin, L. Y., Tse, A. C., Heung, V., \& Yim, F. H. (2005). An analysis of the relationship between market orientation and business performance in the hotel industry. International Journal of Hospitality Management, 24, 555577.

Sukati, I., Hamid, A. B., Baharun, R., Yusoff, R. M., \& Anuar, M. A. (2012). The effect of organizational practices on supply chain agility: An empirical investigation on Malaysia manufacturing industry. Procedia-Social and Behavioral Sciences, 40, 274-281.

Swafford, P. M., Ghosh, S. \& Murthy, N. 2006. The antecedents of supply chain agility of a firm: Scale development and model testing. Journal of Operations Management, 24, 170-188.

Swafford, P. M., Ghosh, S., \& Murthy, N. (2008). Achieving supply chain agility through IT integration and flexibility. International Journal of Production Economics, 116, 288-297. 
IT Integration and Supply Chain Agility on Market Performance (A Proposed Study)

Teece, D. J. (2007). Explicating dynamic capabilities: The nature and microfoundations of (sustainable) enterprise performance. Strategic Management Journal, 28, 1319-1350.

Teece, D. J., Pisano, G., \& Shuen, A. (1997). Dynamic capabilities and strategic management: Organizing for innovation and growth. USA: Oxford University Press.

The Global Information Technology Report. (2016). Innovating in the Digital Economy. Business School, JOHNSON Cornell University. New York (p.135).

Tippins, M. J., \& Sohi, R. S. (2003). IT competency and firm performance: Is organizational learning a missing link? Strategic Management Journal, 24, 745-761.

Tse, Y. K., Zhang, M., Akhtar, P., \& MacBryde, J. (2016). Embracing supply chain agility: An investigation in the electronics industry. Supply Chain Management: An International Journal, 21, 140-156.

Tseng, P.-H., \& Liao, C.-H. (2015). Supply chain integration, information technology, market orientation and firm performance in container shipping firms. The International Journal of Logistics Management, 26, 82-106.

van Hoek, R. I., Harrison, A., \& Christopher, M. (2001). Measuring agile capabilities in the supply chain. International Journal of Operations \& Production Management, 21, 126-148.

Wagner, S. M., \& Silveira, C. V. (2012). Managing risks in just-in-sequence supply networks: Exploratory evidence from automakers. Engineering Management, IEEE Transactions on, 59, 52-64.

Wernerfelt, B. (1984). A resource-based view of the firm. Strategic Management Journal, 5, 171-180.

Wong, W., \& Wong, K. (2011). Supply chain management, knowledge management capability, and their linkages towards firm performance. Business Process Management Journal, 17, 940-964.

World Bank. (2016). International LPI Global Ranking. Available at http://lpi.worldbank.org/international/global

Wu, F., Yeniyurt, S., Kim, D., \& Cavusgil, S. T. (2006). The impact of information technology on supply chain capabilities and firm performance: A resource-based view. Industrial Marketing Management, 35, 493-504.

Wu, K.-J., Tseng, M.-L., Chiu, A. S. F., \& Lim, M. K. (in press). Achieving competitive advantage through supply chain agility under uncertainty: A novel multi-criteria decision-making structure. International Journal of Production Economics,

Yusuf, Y. Y., \& Adeleye, E. O. (2002). A comparative study of lean and agile manufacturing with a related survey of current practices in the UK. International Journal of Production Research, 40, 4545-4562.

Yusuf, Y. Y., Gunasekaran, A., Adeleye, E. O., \& Sivayoganathan, K. (2004). Agile supply chain capabilities: Determinants of competitive objectives. European Journal of Operational Research, 159, 379-392.

Zain, M., Rose, R. C., Abdullah, I., \& Masrom, M. (2005). The relationship between information technology acceptance and organizational agility in Malaysia. Information \& Management, 42, 829-839.

\section{BIOGRAPHIES}

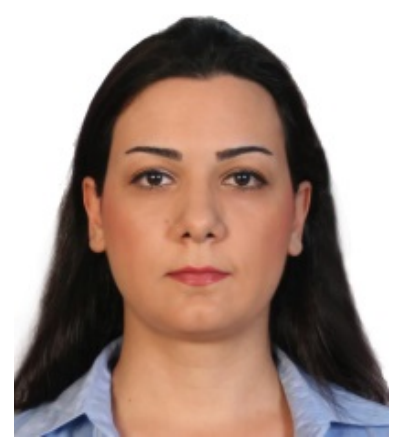

Dr Shaghyegh Maleki Far is a lecturer in Logistics and Supply Chain Management from RMIT University (Vietnam). She obtained her Doctor of Philosophy in Management with specialization in Operations Management from Universiti Teknologi Malaysia (UTM) which is preceded by a Master of Business Administration and a Bachelor of Industrial Engineering (Planning and Systems Analysis). Her research interests are in the areas of Logistics and Supply Chain Management, Operations Management, International Business, Outsourcing and Retails and Service Logistics. 


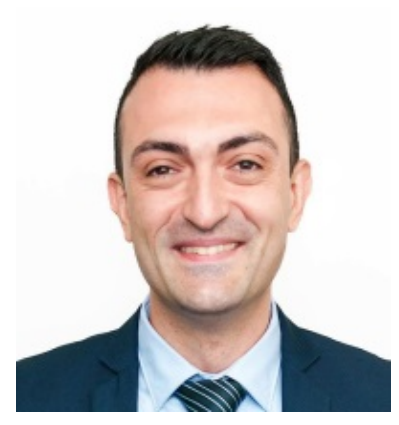

Dr. Mohammadreza Akbari is a lecturer in Logistics and Supply Chain Management from RMIT University Vietnam. He holds a Doctorate in Business Administration (DBA) in Business and Management (Logistics and Supply Chain Management) from the Victoria University (Australia), MBA in International Business, and a Bachelor of Business Administration and Commerce. His research interests are in the areas of Logistics and Supply Chain Management, Operations Management, International Business, Outsourcing, and Business Process Re-engineering (BPR).

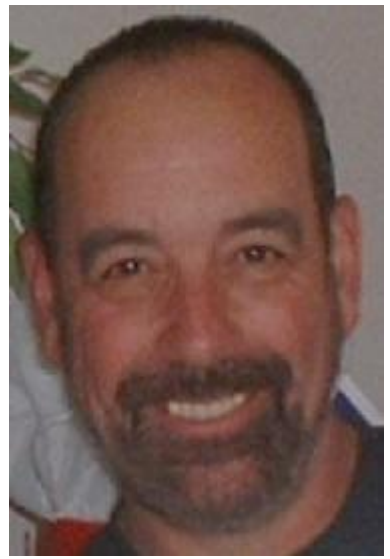

Dr. Steven Clarke (MBA, PhD) is a lecturer in global entrepreneurship, new venture creation, management and marketing at RMIT University (Vietnam). He has consulted for Fortune 500 companies and has extensive experience in the China market. In addition, he has more than 25 years of experience in International Business at Federated Department Stores (Macy's, Bloomingdales), May Department Stores, Carter Hawley Hale Department Stores, Eddie Bauer, National Football League (NFL), Arnold Palmer Golf Design, Central Department Stores (Thailand), Robinson Department Stores (Philippines), and \#1 Department Store (China). His research interests are in the areas of cross-cultural international business including Strategic Management, Marketing, Negotiations, and Foreign Market Entry. 